620.193

\title{
DIAGNOSTICS, RELIABILITY IMPROVEMENT AND A RESIDUAL RESOURCE OF SOME PROTECTION SYSTEMS
}

- • ух чев, - • мирнов, • • оробьев, • • их лев

I. S. Sukhachev, O. V. Smirnov, S. V. Vorobjeva, T. V. Mikhaleva

юменский госуд рственный нефтег зовый университет, г. юмень

нкт- етербургский госуд рственный университет, г. нкт- етербург

лючевые слов :молниез щит ; з земление

Key words: lightning guard; grounding

ри проектиров нии, строительстве и эксплу т ции зд ний, сооружений и коммуник ций промышленного н зн чения, включ я нефтег зохр нилищ, компрессорные ст нции, м гистр льные трубопроводы, системы электроэнергетики, инфр структуру осв ив емых территорий, должны быть предусмотрены мероприятия по з щите от прямых уд ров молнии, перен пряжений, з щите от других вторичных воздействий. собенно кту льны т кие проблемы при ре лиз ции мероприятий и технологий, свя3 нных с предотвр щением з грязнений и очисткой конт ктных поверхностей нефтег зового оборудов ния [1].

бъект ми 3 щиты могут быть обычные и специ льные объекты с огр ниченной оп сностью, с оп сностью для непосредственного окружения и для экологии. специльным объект м относятся предприятия, содерж щие электрост нции и пож рооп сные производств ; нефтеперер 6 тыв ющие предприятия и з пр вочные ст нции; химические $з$ воды, томные электрост нции, биохимические ф брики и л бор тории. ри прямых уд р х молнии в н земные объекты и при межобл чных р зряд х молнии в упомянутых объект х могут возникнуть пож ры, взрывы, н рушения технологических процессов, выход из строя силового оборудов ния, электронных устройств упр вления и регулиров ния, н рушения экологической обст новки, что сопровожд ется ущерб ми, исчисляемыми миллион ми долл ров или евро.

олниеприемник обяз тельно з земляют, и з землитель формируется из одного или нескольких подземных з земляющих электродов (вертик льных или горизонт льных).

ри удельном сопротивлении грунт 100 м м ток молнии р стек ется по его зн чительному объему. ри уд ре молнии в стержневой молниеотвод, з землитель которого выполнен в виде полусферы ди метром $\mathrm{d}=0,5$ м, ток молнии I будет симметрично стек ть с поверхности мет ллической полусферы. ля средней по силе молнии с током $310^{4}$ плотность ток $u$ гового н пряжения сост вит примерно 7,6 $10^{4} / \mathrm{m}^{2}$.

же при грунте с $\rho \approx 100$ м м величин ш гового н пряжения сост вляет $7,610^{5}$ /м, и по мере уд ления от з землителя н пряженность электрического поля н чин ет быстро сниж ться и уже н р сстоянии 10 м приблизительно р вн $510^{3} / \mathrm{M}$. ремя действия высокого н пряжения, к к и длительность ток молнии, сост вляет 0,1 миллисекунды.

п сное для жизни ш говое н пряжение может сохр няться н дост точно большом $\mathrm{p}$ сстоянии от точки уд $\mathrm{p}$ молнии. землители, к к пр вило, монтируют из протяженных шин или стержней. еличин их электрического поля сниж ется н много медленнее.

щит при помощи молниеотводов может быть шунтиров н поверхностью земли или ее толщей при определенной вл жности последней. огд н пряженность электрического поля увеличив ется до 1 /М, в толще грунт, который предст вляет собой дисперсную систему, и где н ходится з земление, н чин ется иониз ция. ти процессы связ ны с физической и коллоидной химией, с электролитическими и поверхностными явлениями, теоретическими основ ми электротехники.

к пр вило, дисперсии, в том числе предст вленные грунт ми и водными систем ми, гетерогенны, термодин мически и грег тивно неустойчивы, что и обусловлив ется их физико-химическими и молекулярно-кинетическими свойств ми. силу опре- 
деленного соотношения сил сцепления и сил отт лкив ния, воздействия ко гулянтов или внешних силовых полей грег ты и коллоидные ч стицы могут быть устойчивы к ко гуляции или, н оборот, ко гулиров ть и обр зовыв ть флокуляционные структуры. оздействие р зности потенци лов н чин ет использов ться при устройстве з земления или его реконструкции, когд восст н влив ют исходное или повышенное зн чение электропроводимости системы. ричиной неустойчивости дисперсной системы т кже является больш я положительн я свободн я поверхностн я энергия, которую систем стремится уменьшить [2].

онятия грег тивной (способность сопротивляться обр зов нию грег тов) и седимент ционной (способность к р ссл ив нию) устойчивости кту льны для поним ния процессов, происходящих под действием внешнего электрического поля, генерирующего электрический р зряд в тмосфере или коронный р зряд $\quad$, и под действием собственного поля поляризов нных внешним полем полидисперсных ч стиц грунт ,

т кже полем ветвей искрового р зряд . определенных условиях последний приводит к росту пл зменного к н л , который скользит вдоль поверхности грунт , слегк проник я внутрь него и обр зуя борозды в грунте. н лы, их может быть несколько (рис. 1), могут продвиг ться от мест уд р молнии н десятки метров, и их н до р ссм трив ть к к продолжение молнии вдоль поверхности земли или в ее толще. ок в к н л х сост вляет десятки процентов от ток молнии, темпер тур — выше $6000^{0}$. ри конт кте т кого к н л с зоной протечек топлив н нефтен ливной эст к де или с подземным к белем, н пример, телефонным или упр вляющим микроэлектронной системой, естественны соответствующие последствия.

ех низм формиров ния искрового к н л вдоль проводящих поверхностей отлич ется тем, что обеспечив ет р звитие к н л в сл бых полях с весьм высокими скоростями.

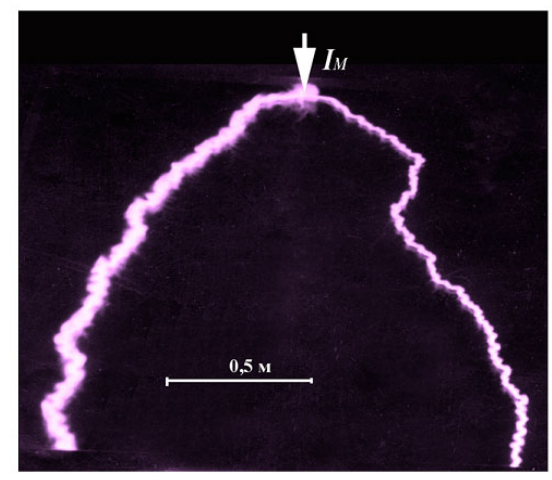

исунок. скровые к лы в грунте при р стек нии ток молнии [3]

блюд ются случ и поп д ния ветвей молнии в коммуник ции или з землитель объект , з щищенного молниеотвод ми. огд тр диционный путь сверху перекрыт, молния прорыв ется к объекту снизу, прокл дыв я обходной к н л в земле, формируя из ее дисперсных ч стиц мостики проводимости. сть основ ния счит ть, что конт кт к н л скользящего р зряд с горючими м тери л ми (к к, возможно, это было в онде) - не менее ч ст я причин пож $\mathrm{p}$, чем прямой уд р молнии.

ри н хождении обслужив ющего персон л или других р ботников предприятия в зоне электрического поля, генерируемого искровыми к н л ми, весьм высок вероятность лет льного исход .

н логично росту цепочек из ч стиц з грязнений в тр нсформ торном м сле при межвитковых 3 мык ниях в г зовл жной дисперсионной среде грунт из его ч стиц могут формиров ться цепочки проводимости некоторых ветвей р зряд .

ин мик электропроводящих свойств грунт меняется в з висимости от клим тических условий регион , что необходимо учитыв ть при ди гностике и прогнозе ост - 
точного ресурс молниез щиты и з земления. то к с ется и з земления коронирующих проводов при постоянном н пряжении и з земленных тросов [4].

дной из причин н рушения общего норм тивного сопротивления устройств 3 земления и ктивной молниез щиты, в том числе по условиям безоп сности, может быть большое сопротивление конт ктов з земляющей цепи, которое увеличив ется в процессе эксплу т ции. ля приборных систем контроля сложных измерительных и втом тических комплексов можно выделить некоторые общие и х р ктерные свойстB [5]:

- $\mathrm{p}$ знообр зные функцион льные и схемные решения к к в информ ционных д тчик х генериров ния, т к и усиления сигн л [6];

- применение в одной электросистеме р зличных н пряжений для приборов дигностики и, н пример, процессов и пп р тов природоохр нных технологий — электрофильтров, пп р тов , систем электрообр ботки дисперсий с р зными сред ми и т. д;

- низкие зн чения ток первичной информ ции при оценке п р метров среды и ресурсов, н пример, в эроионометр х, дозиметр х, г зо н лиз тор х и т. д.;

- необходимость повышения н дежности и помехоустойчивости;

- использов ние микропроцессорной техники.

ф ктор м, повыш ющим эксплу т ционные свойств объектов информ тиз ции, упр вления и втом тики в нефтег зодобыче и перер ботке, включ я измерительные системы, относится н дежно выполненное з земление, что прямо или косвенно повыш ет н дежность р боты систем и повыш ет достоверность получ емой информ ции.

роблем н дежности и безотк зности з земления с учетом современных требов ний помехоустойчивости в комплексе с электробезоп сностью возникл ср внительно нед вно. жными являются д нные о полном сопротивлении з земляющей цепи, величин х электрических сопротивлений конт кт между корпусом оборудов ния и 3 земляющей шиной, что позволило бы н метить конкретные пути повышения н дежности и к честв з землений оборудов ния и схем нефтег зового оборудов ния, следов тельно, и продления их ост точного ресурс .

о всех случ ях, будь то з земление через конструкцию или з земление непосредственно проводом, к к, н пример, для переносных приборов (подчеркив ется в ), необходимо обеспечение н дежного присоединения. исследов нии . . пустин [5] проводилось изучение призн ков, х р ктеризующих состояние цепей между з земляющей шиной и корпусом оборудов ния н м шиностроительных предприятиях и в л бор тории им . . муров им. . . льянов ( енин ). езульт ты ди гностики, включ я измерения, общее число которых доходило до 10 000, позволили предск 3 ть возможные отклонения и предотвр тить н рушения норм льного режим р боты з земления. ыли сдел ны следующие выводы [5].

тносительно большой процент р зрывов цепи при вводе электрооборудов ния в эксплу т цию объясняется дефект ми монт ж. пыт пок зыв ет, что при устр нении грубых дефектов монт ж (не подж тые г йки и т. д.) можно довести число конт ктов, имеющих сопротивление менее 0,1 м, пр ктически до 94-95 \% от общего числ конт ктов. онт кты в конструкциях н ср внительно большом р сстоянии от з земляемого объект сост вляют 5-6\%. меньшение сопротивления всей з земляющей цепи в этом случ е может быть достигнуто при повторных или многокр тных з землениях конструкции.

ри относительно больших зн чениях сопротивлений конт ктов и з земляющей цепи в целом в схем х может иметь место н рушение эквипотенци льных нулевых зон, и т кое н рушение в процессе эксплу т ции может увеличиться. озможно, именно этим можно объяснить ряд отк зов в р боте измерительных цепей и цепей упр вления электрооборудов ния тр нспортных средств, в элемент х электросн бжения в хтовых поселков, приборов профессион льного отбор , среды, информ ции, пп р тов природоохр нных и нефтехимических технологий.

ерен пряжения, вызв нные, к к пр вило, естественными причин ми, влекут 3 собой структурообр зов ние из ч стиц м тери л электродов з земления и высокодис- 
персных ч стиц грунт при н личии вл ги к к дисперсионной среды, что т кже необходимо учитыв ть при определении общего сопротивления нодной подсистемы.

и гностик состояния конт ктов з земляющей цепи позволяет повысить н дежность р боты природоохр нных электротехнологий, процессов и электрических пп р тов и оценить их ост точный ресурс.

ким обр зом, при ди гностике, идентифик ции н дежности, прогнозиров нии ост точного ресурс сост вляющих р зличных систем необходимо измерение сопротивления конт ктов и р спозн в ние р зрывов з земляющих устройств, учет х р ктеристик з землителей дисперсного грунт, устр нение дефектов строительномонт жных р бот.

ри р зр ботке прогр мм втом тического р счет молниез щиты целесообр зно учитыв ть физико-химические и электропроводящие х р ктеристики грунтов, предст вляющих собой многоф зные дисперсные системы.

писок литер турь

1. мирнов . ., оробьев . ., мирнов . . онцепции предотвр щения з грязнений конт ктных поверхностей г зового оборудов ния // зов я промышленность. - 2014. - № 7. - . 92-96.

2. оюцкий . . у урс коллоидной химии. - .: имия, 1975. -512 с.

3. зелян . ., йзер . . изик молнии и молниез щиты. - $\quad . \quad$ изм тлит, 2001. -320 с.

4. опков . . . оронный р зряд и линии сверхвысокого н пряжения. збр нные труды. - . $\quad$ у ук, 1990.

5. пустин . . земление к к средство н дежной р боты приборов среды, простр нств и биоинформ ции. « руды », вып. 51, 1966. - .35-38.

6. мирнов . ., т нов . . некоторых перспективных р зр ботк х в обл сти измерительной техники // 3вестия вузов. ефть и з. - юмень: юм , 2013, № 6. - . 107-110.

ведения об втор $x$

ух чев лья ергеевич, спир нтк федры « лектроэнергетик», юменский госуд рственный нефтег зовый университет, г. юмень, тел. 89829210000, e-mail: ilya@suhachev.com

мирнов лег л димирович, д. т. н., профессор кфедры « лектроэнергетик», юменский госуд рственный нефтег зовый университет, г. юмень, тел. 89129275192, e-mail:svorobeva@mail.ru

оробьев им сильевн, д. т. н., профессор к федры « ехносферн я безоп сность», юменский госуд рственный нефтег зовый университет, г. юмень, тел. 89129275191, e-mail: svorobeva@mail.ru

их лев тьян икторовн, спир нтк федры "рикл дня м тем тик процессов упр вления», нктетербургский госуд рственный университет,г. нкт етербург,тел.89219703273,e-mail: izmastarshaya@ya.ru
Information about the authors

Sukhachev I. S., postgraduate of the chair «Electroenergetics», Tyumen State Oil and Gas University, phone: 89829210000,e-mail: ilya@suhachev.com

Smirnov O.V., doctor of Technical Sciences, professor of the chair "Electroenergetics», Tyumen State Oil and Gas University, phone: 89129275192, e-mail: oleg_smirniv_1940@mail.ru

Vorobjeva S. V., Doctor of Science in Engineering, professor of the chair "Technosphere Safety», Tyumen State Oil and Gas University, phone: 89129275191, email: svorobeva@mail.ru

Mihaleva T. V., postgraduate of the chair «Applied mathematics of control processes», Saint-Petersburg State University, phone: 89219703273 , e-mail: izmastarshaya@ya.ru 